\title{
MENUMBUHKEMBANGKAN WIRAUSAHA MAHASISWA DAN ALUMNI MELALUI PROGRAM IPTEK BAGI KEWIRAUSAHAAN DI UNIVERSITAS MERDEKA MALANG
}

\author{
Hery Budiyanto ${ }^{1)}$, Mochammad Rofieq ${ }^{2)}$ \\ Teknik Arsitektur Universitas Merdeka Malang ${ }^{1}$ \\ Teknik Industri Universitas Merdeka Malang ${ }^{2}$
}

\begin{abstract}
ABSTRAK
Sesuai dengan Pola Ilmiah Pokok Universitas Merdeka Malang, maka IbK di Universitas Merdeka Malang merupakan suatu program dengan misi menghasilkan mahasiswa berwirausaha yang mandiri berbasis ipteks, melalui program yang terintegrasi dengan melibatkan para dosen pengelola IbK, Narasumber, Perusahaan dan Institusi kewirausahaan di luar kampus. Kegiatan-kegiatan IbK Universitas Merdeka Malang antara lain: pengembangan jiwa wirausaha, pelatihan manajemen dan skills usaha bagi tenant, konsultasi bisnis, peninjauan di perusahaan yang sudah mapan serta memfasilitasi tenant dalam berwirausaha untuk menghasilkan wirausaha baru. Tenant membentuk dan meningkatkan ketrampilan untuk menunjang manajemen dan pemasaran produk di laboratorium program studi yang telah dipersiapkan. Untuk memperluas wawasan dan jaringan pemasaran, IbK juga berkolaborasi dengan lembaga-lembaga yang terkait dengan pengembangan kewirausahaan, yaitu Asosiasi Perajin Kota Malang, Kamar Dagang dan Industri Kota Malang, Rumah Baca Aqil, dan lain-lain. Pelatihan skills dan manajemen dilaksanakan untuk memberikan pengetahuan kewirausahaan, mendorong tumbuhnya motivasi berwirausaha, meningkatkan pemahaman manajemen (organisasi, produksi, keuangan, dan pemasaran) serta membuat rencana bisnis atau studi kelayakan usaha. Beberapa tenant mengikuti magang pada perusahaan UKM mitra untuk memberikan pengalaman praktis kewirausahaan kepada mahasiswa dengan cara ikut bekerja sehari-hari pada unit usaha tersebut. Mahasiswa yang telah mulai berwirausaha, mahasiswa Program Kreativitas Mahasiswa Kewirausahaan (PKMK) atau Program Kreativitas Mahasiswa (PKM) lainnya, alumni yang berminat atau baru merintis usaha bisa menyempurnakan kegiatan kewirausahaan yang telah dilakukan sebelumnya,

untuk meningkatkan usahanya. Pengelola IbK Universitas Merdeka Malang menggali jenis komoditas bisnis para tenant sesuai dengan bakat dan minatnya. Unit layanan program IbK Universitas Merdeka Malang tahun 2016 melakukan pembinaan motivasi kewirausahaan kepada 30 mahasiswa yang seluruhnya adalah mahasiswa PKMK/PKM lainnya, mahasiswa yang merintis usaha baru dan alumni, kemudian dari jumlah tersebut dipilih 20 orang menjadi tenant calon wirausaha. Di akhir program telah berhasil mengentaskan 8 mahasiswa dan alumni menjadi wirausaha baru dengan berbagai bidang usaha, antara lain: kerajinan kayu, tas tali, jilbab, perca kain, usaha kuliner kantin kampus dan donat sayur serta satu usaha jasa per-sewaan sepeda motor. Pembinaan lanjutan para tenant IbK dilakukan oleh Unit Inkubator Bisnis Universitas Merdeka Malang yang dikelola oleh LPPM Universitas Merdeka Malang.
\end{abstract}

Kata kunci: ipteks, kewirausahaan, mandiri, tenant, manajemen, skills

\section{PENDAHULUAN}

Universitas Merdeka Malang mempunyai pola ilmiah pokok "kewirausahaan" dimana sejak tahun 1988 hingga saat ini telah melaksanakan programprogram pengembangan kewirausahaan, antara lain: Program Usaha Mandiri dan Kewirausahaan (PUMK), Program Revitalisasi Desa, Program pembinaan berupa kursus, pelatihan dan pendampingan yang menitikberatkan pada peningkatan manajerial dan ketrampilan kepada Generasi Muda Terdidik, SMA, Mahasiswa, UKM, dan Masyarakat umum. Dalam hal permodalan, dilaksanakan kegiatan konsultasi bisnis melalui Konsultan Keuangan Mitra Bank (KKMB) merupakan hasil kerjasama Universitas Merdeka Malang dengan 3 Bank, yaitu Bank BNI 46, Bank Mandiri dan Bank Jatim. Unmer juga bekerjasama dengan berbagai pihak, antara lain Yayasan Damandiri sejak tahun 2004 melaksanakan program awal Bantuan Belajar Mandiri (BBM), Life Skill, Guru Magang dan Program Pemberdayaan Masyarakat Sekitar Kampus. 
Dalam hal wirausaha mahasiswa, terdapat berbagai Produk/komoditas yang sudah dihasilkan atau dijual oleh para mahasiswa dalam masa perkuliahan di Universitas Merdeka Malang, antara lain Mahasiswa peserta Program Kreativitas Mahasiswa Kewirausahaan pada tahun 2015 berjumlah 21 orang dengan berbagai komoditas/produk, antara lain: souvenir kayu, jok motor, tas, sandal, aksesories, gorden, dan rombong makanan. Mahasiswa peserta Program Kreativitas Mahasiswa selain Kewirausahaan pada tahun 2015 berjumlah 42 orang dengan kajian berbagai komoditas/produk, antara lain: komponen kendaraan, industri logam, makanan, dan pariwisata. Selain itu banyak mahasiswa yang merintis usaha baru dengan komoditas/ produk: sanitair, kaos, sablon, souvenir. Alumni Unmer Malang yang merintis usaha baru sejumlah lebih dari 100 orang dengan berbagai produk/komoditas, antara lain: kaos/sablon, perdagangan, jasa konsultasi, dan lainlain.

Ipteks bagi Kewirausahaan Universitas Merdeka Malang merupakan fasilitas yang dikelola oleh para dosen dan staf Universitas Merdeka Malang yang menawarkan paket terpadu kepada para pengusaha atau alumni dan mahasiswa tingkat akhir. Paket terpadu tersebut meliputi: a) sarana fisik berupa kantor, laboratorium, dan workshop baik di kampus maupun di perusahaan mitra Unmer Malang yang dapat dipakai bersama; b) kesempatan akses dan pembentukan jaringan kerja; c) pelayanan konsultasi; d) pembentukan jaringan kerja antar pengusaha dan asosiasi pengusaha; e) pengembangan produk menjadi produk komersial. IbK Unmer Malang merupakan suatu sistem yang dapat memberikan peran lebih dari sekedar tempat diselenggarakannya pelatihan manajemen bagi tenant, tetapi mampu membangkitkan, membina dan mengembangan wirausaha secara berkesinambungan sehingga menjadi wirausaha yang tangguh (Kasali, 2010) dan inovatif (Pujantiyo, 2006). Ipteks bagi Kewirausahaan Unmer Malang merupakan unit organisasi yang menyediakan sarana dan prasarana serta pelayanan terpadu dalam mengembangkan wirausaha baru agar berkembang menjadi pengusaha tangguhdan mandiri. Dengan demikian diharapkan Ipteks bagi Kewirausahaan Unmer Malang mempunyai peran dalam mendorong laju pertumbuhan dan kemajuan ekonomi regional maupun nasional untuk mencapai masyarakat yang lebih sejahtera.

Metode pengoperasian di Ipteks bagi kewirausahaan mengikuti prinsip "learning by doing" (Hackathorn, 2011) yaitu mengajak para tenant untuk memperhatikan, mempelajari, mencoba membuat desain dan melakukan/menjalankan produksi, turut serta menangani pemasaran, dan melakukan evaluasi terhadap seluruh aktivitas yang telah dijalankan. Harapan dari penggunaan metode ini adalah agar para peserta dapat meresapi proses pembuatan desain, produksi hingga pemasaran, sehingga pada akhirnya akan mudah untuk mengadopsi hal-hal yang telah dialami di IbK untuk dibuat dan dikembangkan di lingkungan masingmasing. Jadi, peranan IbK adalah sebagai tempat pendadaran terhadap para mahasiswa dan alumni universitas agar jiwa wirausaha mereka menjadi sebuah sikap wirausaha yang mandiri.

\section{Tujuan}

Kegiatan IbK bertujuan untuk membina peserta IbK untuk merintis dan mendirikan usaha yang mencakup bidang usaha sebagai berikut : Bidang kuliner, Bidang kerajinan, Bidang jasa, Bidang teknologi informasi

\section{METODE KEGIATAN}

Proses seleksi calon peserta program kewirausahaan di Universitas Merdeka Malang (recruitment tenant) dilakukan secara bertahap sebagai berikut: (1) melakukan sosialisasi kepada ketua-ketua jurusan dan mahasiswa yang mendapatkan hibah PKMK/non PKMK serta mahasiswa dan alumni yang berminat di bidang kewirausahaan, (2) Melakukan seleksi (recruitment test) terhadap pendaftar program IbK. (3) sejumlah (30) tiga puluh mahasiswa PKMK/Mahasiswa non PKMK yang sudah berhasil lolos dari recruitment test mengikuti program perkuliahan kewirausahaan (KWU), tapi hanya 23 (dua puluh) mahasiswa dengan urutan ranking terbaik yang diperbolehkan melanjutkan untuk mengikuti program entrepreneurship capacity building, yaitu (1) diklat kewirausahaan, (2) magang kewirausahaan, dan (3) Inkubator kewirausahaan. Dari 20 mahasiswa yang digodok dalam program pembentukan kapasitas wirausaha dapat dihasilkan 8-10 mahasiswa wirausaha baru mandiri per tahun yang siap berkompetisi di masyarakat (bussines establishment). Pola recruitment peserta program kewirausahaan IbK Unmer Malang, seperti ditunjukkan pada gambar 1 . 


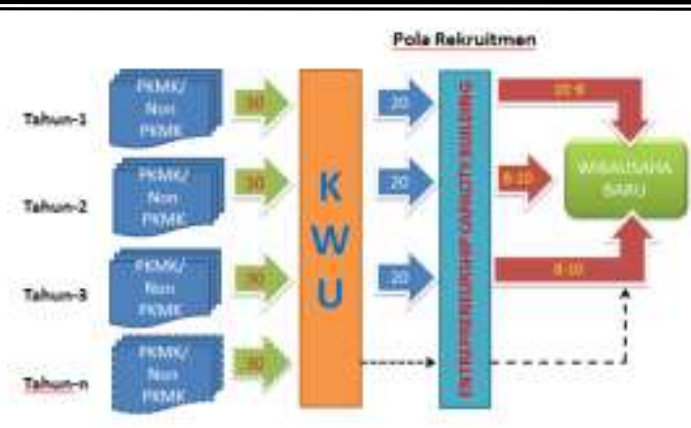

Gb 1: Pola Rekruitmen Peserta IbK

Metode pendekatan IbK dalam konteks pemberdayaan potensi entrepreneurship mahasiswa mahasiswa menggunakan metode PALS (Participatory Action Learning System). Prinsip dasar dari metode PALS adalah pelibatan mahasiswa dalam proses pembelajaran aktif partisipan dalam program kewirausahaan (entrepreneurship) secara alamiah dengan segala pendekatan sehingga membentuk suatu sistem interaksi pembelajaran secara partisipatif, baik secara personal maupun komunal. Metode PALS menitikberatkan pada transformasi kegiatankegiatan yang telah ada untuk diusahakan dibawa pada perubahan-perubahan ke arah perbaikan kondisi entrepreneurship mahasiswa melalui (1) fase penyadaran kewirausahaan (awareness), (2) fase pengkapasitasan (capaciting) dan pendampingan (scaffolding) kewirausahaan (entrepreneurship capacity building), dan (3) fase pelembagaan (institutionalization) usaha baru sebagai wirausana baru. Metode pendekatan IbK dengan metode PALS secara digramatik ditunjukkan pada gambar 2 .

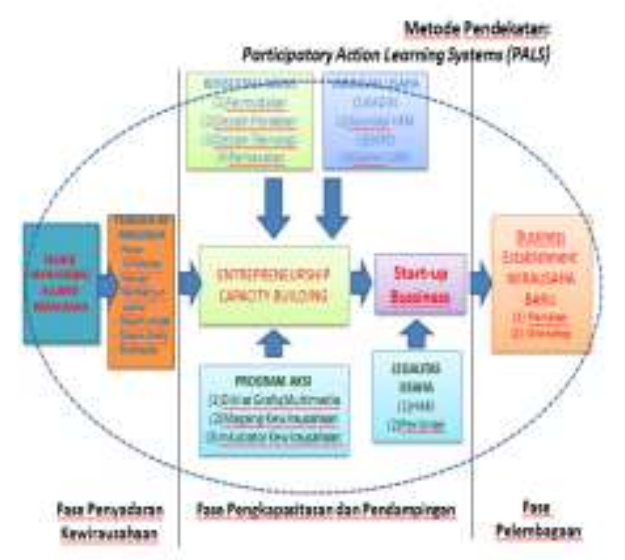

Gb 2: Metode Participatory Action Learning Systems

\section{HASIL DAN PEMBAHASAN}

Sejumlah 28 orang mahasiswa dan alumni terpilih menjadi peserta Program IbK, berasal dari berbagai program studi di Universitas Merdeka Malang sebagaimana diuraikan pada Tabel 1. Pada tahap seleksi dan penjaringan awal, program IbK ini diminati oleh lebih dari 50 mahasiswa dan alumni, dalam pelaksanaan selanjutnya dipilih 28 peserta untuk dibina, dilatih dan dikembangkan sehingga menjadi wirausaha baru yang tangguh. Terdapat 3 fase yang telah dilaksanakan dalam program IbK Unmer Malang, yaitu: 1) fase penyadaran kewirausahaan , 2) fase pengkapasitasan dan pendampingan, 3) fase pelembagaan

Tabel 1: Peserta IbK Unmer Malang

\begin{tabular}{llll} 
NO & \multicolumn{1}{c}{ NAMA } & \multicolumn{1}{c}{ NPK } & $\begin{array}{c}\text { PROGRAM } \\
\text { STUDI }\end{array}$ \\
\hline 1. & Romi Setiawan & 14440007 & T. Industri \\
2. & Ide Bagus Weda P. & 14440004 & T. Industri \\
\hline 3. & Boby Aditya S & 14440010 & T. Industri \\
4. & Nurahman & 14440013 & T. Industri \\
\hline 5. & Erwin D Pambudi & 1444011 & T. Industri \\
6. & Eric Aprilia Santo & 14440006 & T. Industri \\
\hline 7. & Ria Dwi P. S. & 12410022 & T. Sipil \\
8. & Bunga R. & 12410026 & T. Sipil \\
\hline 9. & Ivanda Rovalia & 13411001 & T. Sipil \\
10. & Dwi Putra I. J. & 12410015 & T. Sipil \\
\hline 11. & Yudha P. & 13420007 & T. Mesin \\
12. & Nanda & 13420026 & T. Mesin \\
\hline 13. & Gusti Ngurah A.A. & 14420044 & T. Mesin \\
14 & Indra Wahyu & 13420024 & T. Mesin \\
15. & Zulfikar & 15081002 & Informatika \\
\hline 16. & M. Iqbal & 13430018 & Arsitektur \\
17. & Nia Redhantika & 13430020 & Arsitektur \\
18. & Evi Fitriani & 13430012 & Arsitektur \\
19 & Andika Mardiana & 13430029 & Arsitektur \\
20. & Aldira Saraswati & 13430019 & Arsitektur \\
21. & Wita Mannoradja & 13430032 & Arsitektur \\
22. & Nicke Purnama & 12900041 & Psikologi \\
\hline 23. & Marta Kristiani & 13610001 & D3- \\
24. & Astri Devi & 13228061 & Manajemen \\
25. & Amanda Paramytha & 150221001 & Manajemen \\
26. & Onward H. & 10 & Komunikasi \\
27. & Syarifudi M & 14330039 & \\
28. & Wahyu W. & 14330045 & Komunikasi \\
\hline & & & Adm. Publik \\
\hline
\end{tabular}

a. Fase Penyadaran Kewirausahaan bertujuan membentuk dan mengembangkan sikap dan prilaku 'entrepreneur', yang mampu berkreasi, menciptakan inovasi, dan proaktif dalam menghadapi perkembangan lingkungan. 
Bentuk teknis pelatihan yang diterapkan adalah classical, studi kasus, diskusi, dan simulasi.
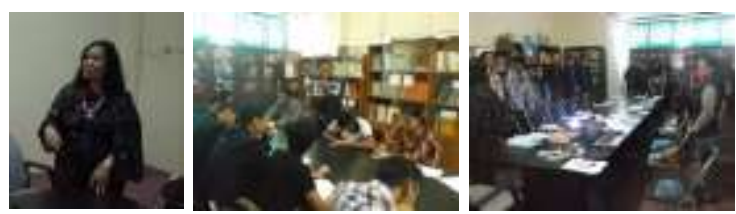

Gb 3: Motivasi Pengembangan Sikap dan Perilaku Entrepreneur

Pembekalan selanjutnya berkaitan dengan cara memulai, mengembangan dan mempertahankan usaha dengan kasus usaha-usaha dibidang kerajinan (handicraft).
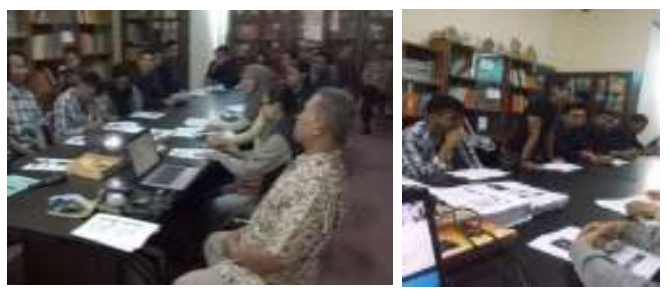

Gb 4 : Membuka, Mengembangkan,

dan Mempertahankan Usaha Handicraft

Pencerahan tentang peran perguruan tinggi umumnya dan khususnya Unmer Malang dalam mendorong mahasiswa dan masyarakat umum dalam menjalankan usaha baik perorangan maupun kelompok. Peran tersebut meliputi berbagai aspek, antara lain: motivasi usaha, permodalan, manajemen, hingga pemasaran produk dan jasa.
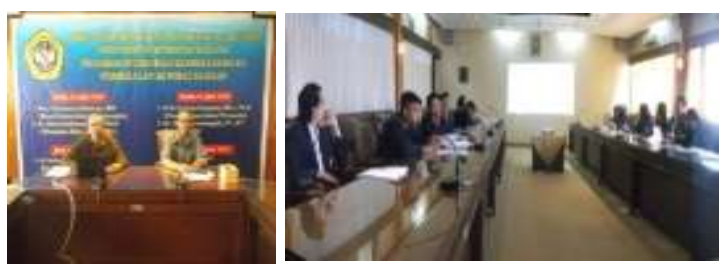

Gb 5 : Materi Peran Unmer Malang dalam Pengembangan Usaha

Dalam hal desain dibahas tentang peran Desain Produk dan Desain Grafis dalam menunjang kegiatan usaha sehingga usaha dapat berkembang.

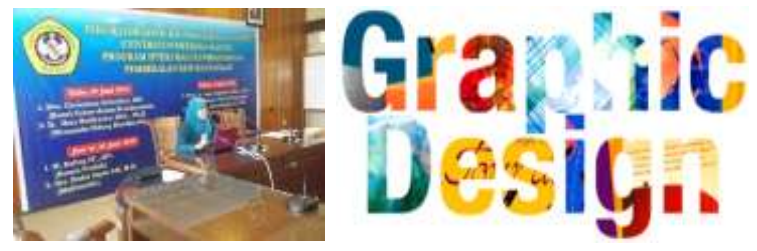

Gambar 6: Materi Desain Grafis

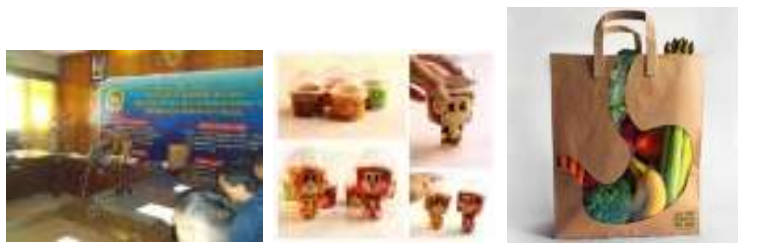

Gb 7: Materi Desain Produk

Pencerahan juga diberikan pegiat kegiatan usaha Multimedia menjelaskan peluang dan prospek bisnis multimedia dan penggunaan multimedia untuk pengembangan bisnis.
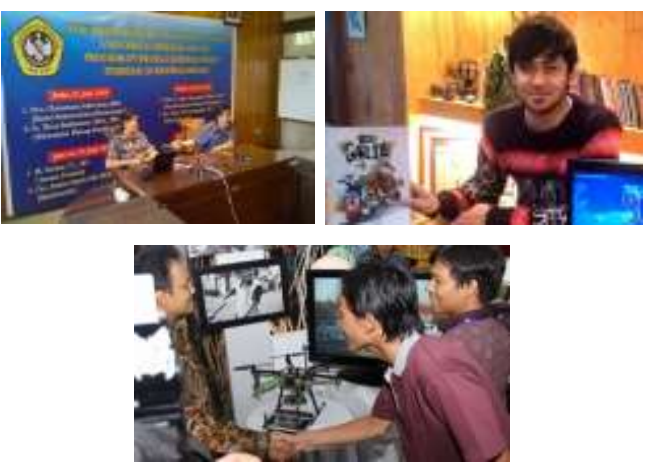

Gb 8 : Materi Bisnis Multimedia

b. Fase Pengkapasitasan dan Pendampingan merupakan fase yang lebih mengarah pada upaya memperkuat perintisan usaha para peserta (tenant). Tahap ini dimulai dengan mengajak seluruh peserta ke unit-unit usaha kecil dan menengah (UKM) di Kota Malang yang telah melaksanakan kegiatan usaha lebih dari 10 tahun dan sudah pernah melakukan penjualan hingga manca negara (export), sehingga dalam interaksi antara peserta IbK dengan pengusaha para peserta IbK mendapat cerita tentang bagaimana memulai usaha, mengembangkan dan mempertahankan usaha. Dalam kegiatan ini beberapa peserta IbK melakukan konsultasi usahanya untuk memantapkan tekad membuka dan memulai usaha.

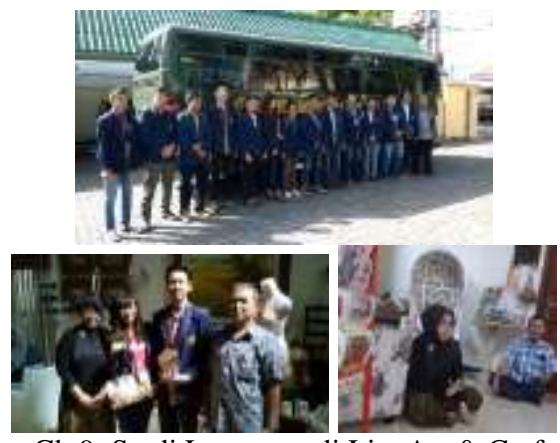

Gb 9: Studi Lapangan di Lita Art \& Craft 

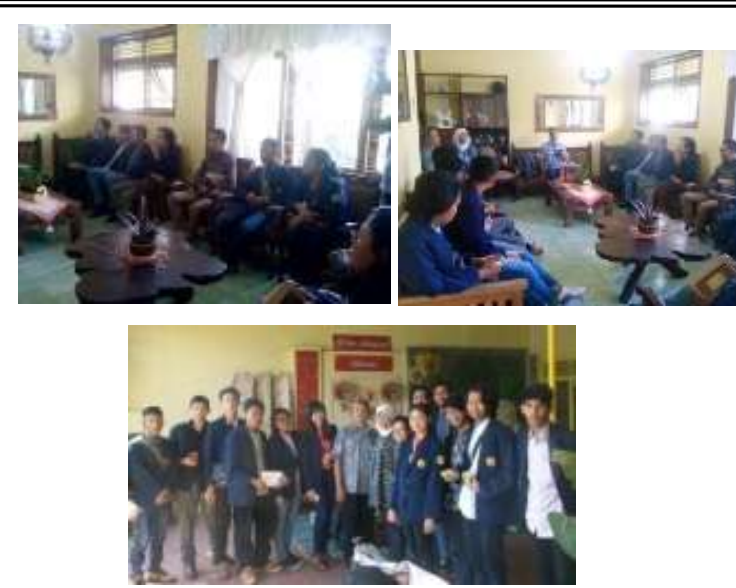

Diskusi \& konsultasi bisnis
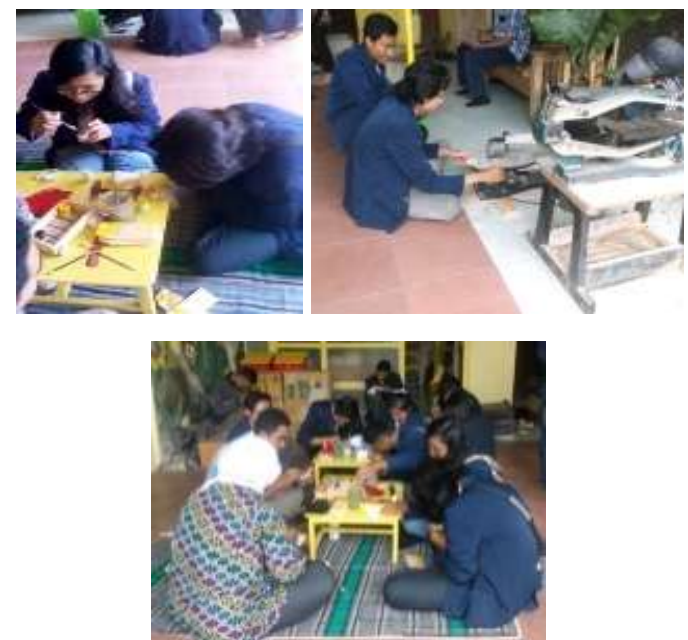

Praktek membuat produk woodcraft

Gb 10: Studi Lapangan di GS4 Woodcraft

Terdapat 2 orang mahasiswa Prodi Arsitektur yang bekerjasama dengan GS4 dimulai sejak mengerjakan PKM-K hingga saat ini magang membuat produk souvenir kayu di sela-sela kegiatan akademis di kampus.

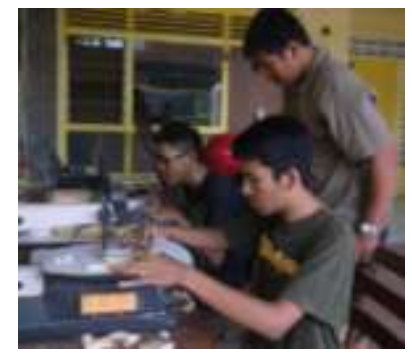

Gb 11: Mahasiswa Peserta IbK Magang di GS4 Woodcraft

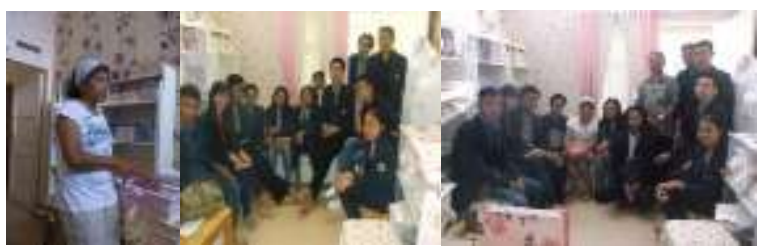

Gb 12 : Studi Lapangan di Maharani Embroidery Handicraft

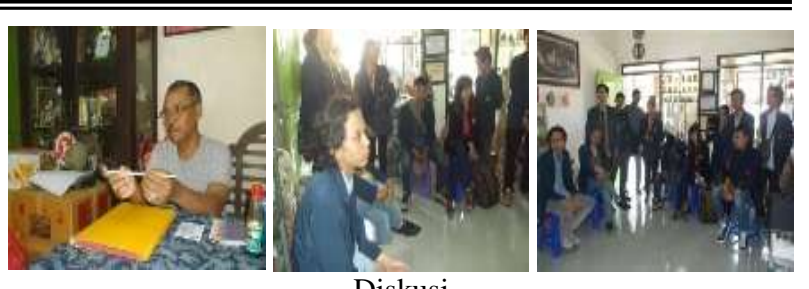

Diskusi

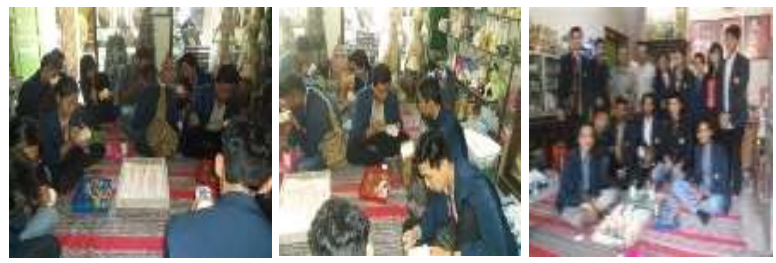

Praktek melukis keramik

Gb 13: Studi Lapangan di Cenderamata Keramik

c. Fase Pelembagaan dilaksanakan dalam rangka menciptakan jaringan kerjasama antara IbK Unmer Malang - Tenant - Lembaga yang prosesnya memanfaatkan keunggulan mitra lembaga

\section{Kerjasama}

Telah dilaksanakan kerjasama dengan beberapa komunitas, antara lain: Ruang Belajar Aqil dan Komunitas Plat-N.

Ruang Belajar Aqil Merupakan komunitas para mahasiswa yang pada taraf belajar baik belajar keilmuan secara umum maupun belajar bisnis. Komunitas ini mempunyai kegiatan yang menampilkan para wirausaha dari mulai awal hingga saat ini melalui tema "Wirausaha dalam Kisah" dengan pembicara antara lain: Jamaluddin (Injers - Kaos \& Pakaian dg Bordir Komputer), Sri Mulyani Hadiwinata (Dea Cake \& Bakery), Hery \& Retno Budiyanto (GS4 Woodcraft), Khaleed Hadi Pranowo (Impuls Space - Interior). Forum ini memperkenalkan dan mendiskripsikan sisi lain dari berbisnis kepada peserta, selain tinjauan strategis dan teknis, nilai yang hendak disampaikan yaitu "Berbisnis adalah Berketetapan dalam Hidup".

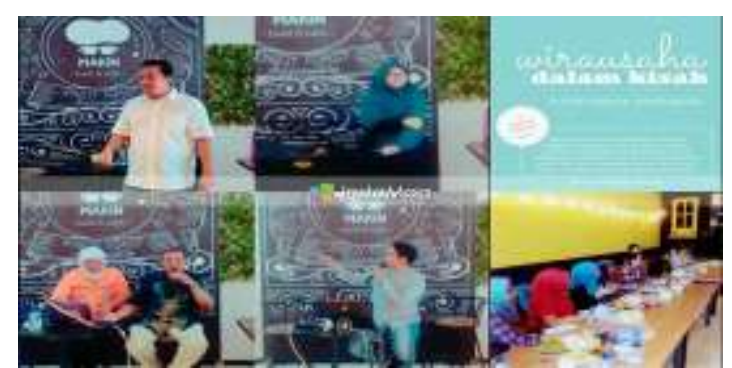

Gb 14: Forum "Wirausaha dalam Kisah".

Komunitas "Crafter Plat-N" yang telah banyak membina dan membantu para pengusaha 
handicraft yang baru dalam berbagai kegiatan. Salah satu yang diikuti kegiatannya oleh para Tenant IbK adalah Parade Handycraft yang kegiatannya meliputi Bazar dan Workshop handicraft.

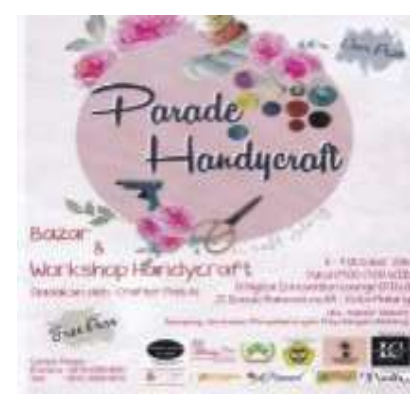

Gb 15: Parade Handicraft

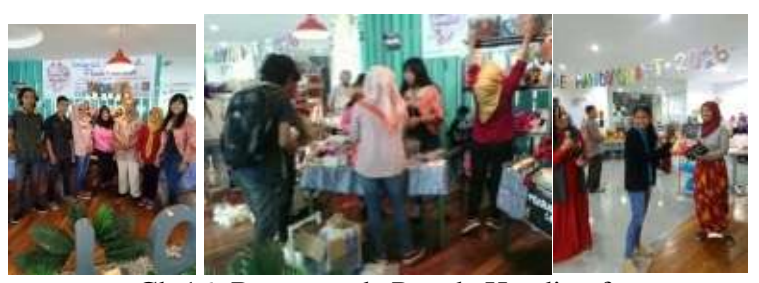

Gb 16: Bazaar pada Parade Handicraft
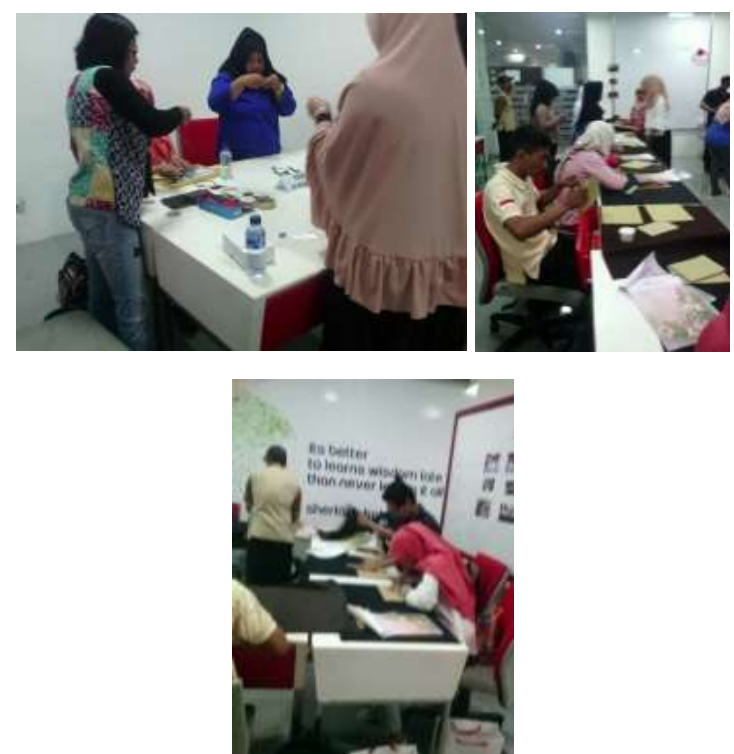

Gb 17: Workshop pada Parade Handicraft

\section{Pemasaran produk dan jasa}

Dalam rangka meningkatkan pasar bagi tenant IbK Unmer Malang, maka telah dilaksanakan kegiatan pemasaran kerjasama dengan beberapa komunitas, antara lain:

- Pemasaran di Kawasan Alun-alun Kota Batu

Sebagai langkah awal program pemasaran, dibawah binaan Program Inkubator Bisnis, LPPM Unmer meyelenggarakan kegiatan pemasaran secara langsung di tempat umum, yaitu Alun-alun Kota Batu pada tanggal 19 November 2016.
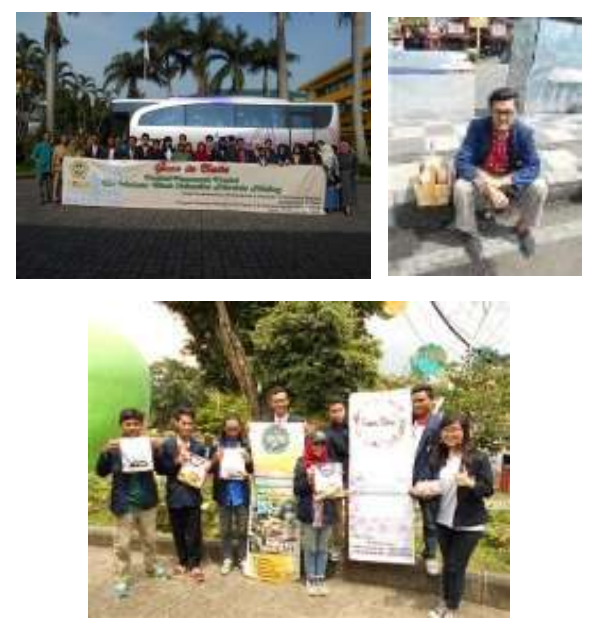

Gb 18: Pemasaran Produk di Kawasan Alun-alun Batu

- Pemasaran di Kawasan Universitas Merdeka Malang

Pemasaran di jalan Terusan Raya Dieng Kawasan Universitas Merdeka Malang dilaksanakan pada tanggal 24 November 2016 sebagai Entrepreneur Day yang diselenggarakan oleh Program Inkubator Bisnis LPPM Unmer Malang.

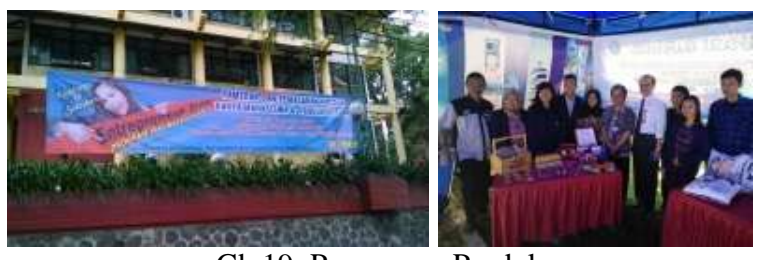

Gb 19: Pemasaran Produk

di Entrepreneur Day Unmer Malang

- Pemasaran melalui Pameran Produk di @MX Mall Malang

Pameran ini diselenggarakan oleh Malang Creative Fushion dalam rangka kegiatan "Malang Mbois", bekerjasama (berkolaborasi) dengan Asosiasi Perajin Kota Malang (APKM) pada tanggal 25-27 November 2016.

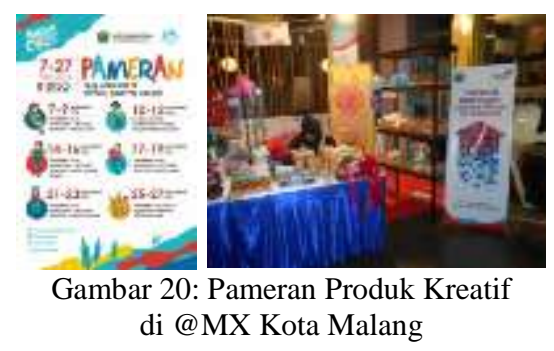


Luaran

Luaran yang dicapai hingga saat ini adalah:

a. Jasa atau produk Wira Usaha Baru (WUB) mahasiswa dan alumni yang memiliki keunggulan ipteks, antara lain:

- produk kerajinan : bunga tangan, kayu (Muhammad Iqbal), tas tali (Gusti Ngurah), aksesori jilbab (Wita Mannoradja), Bucket Bunga Kain (Aldira, Andika, Prabawati), Lukis Kain (Moses)

- makanan ringan : donat sayur (Amanda), coklat kurma (Romi)

- jasa: persewaan sepeda motor (tim mahasiswa mesin).

Sebagian peserta IbK masih belum memutuskan jenis usaha yang akan dijalani, meskipun rintisan usaha sudah dilakukan. Untuk itu diperlukan pemantapan dalam bentuk konsultasi bisnis melibatkan para pelaku usaha yang telah mapan .

b. Pembentukan jaringan usaha tenant dengan stakeholders.

- Ruang Belajar Aqil

- Komunitas Plat-N

Sedang dijajaki pertemuan dengan beberapak pihak, antara lain : Kamar Dagang dan Industri (KADIN) Kota Malang, Dewan Kerajinan Nasional Daerah (Dekranasda) Kota Malang, serta Dinas terkait yaitu: Dinas Perindustrian dan Perdagangan, Dinas Koperasi dan UKM Kota Malang.

\section{KESIMPULAN DAN SARAN}

\subsection{Kesimpulan}

- IbK merupakan program yang tepat untuk menumbuhkembangkan jiwa wirausaha dan mengentaskan wirausaha baru dari kalangan mahasiswa dan alumni perguruan tinggi.

- Peserta IbK telah melalui proses pembinaan meliputi 3 fase, yaitu fase penyadaran kewirausahaan serta Fase Pengkapasitasan, Pendampingan dan Pelembagaan. Beberapa kegiatan fase ketiga masih diperlukan, antara lain penyertaan peserta dalam konsultasi bisnis secara berkelompok maupun pribadi dengan para pelaku bisnis untuk memantapkan usaha masing-masing peserta.

- Peserta IbK mendapatkan pengalaman praktis yang tidak siperoleh dari bangku kuliah sehingga permasalahan-permasalahan lapangan telah mereka ketahui dari interaksi dengan para pelaku usaha dan para narasumber pada sesi pembekalan kewirausahaan.

- Terdapat 8 mahasiswa yang telah memastikan jenis produk dan jasanya.

- Program IbK sangat diperlukan untuk menunjang dan sebagai kelanjutan dari kegiatan kewirausahaan, misalnya: PKM-Kewirausahaan, PKM Gagasan Teknologi, kuliah kewirausahaan.

- Kendala waktu yang berbenturan dengan kegiatan lain, misalnya Praktek Kerja Nyata, Praktek Kerja Lapangan dan Liburan Semester Panjang sering menyulitkan mahasiswa untuk mengikuti program keseluruhan, sehingga memerlukan penjadwalan yang melibatkan dosen dan mahasiswa agar seluruh peserta dapat mengikuti seluruh kegiatan secara lengkap.

\subsection{Saran}

- Program IbK merupakan program pembinaan usaha mahasiswa dan alumni yang lengkap dan terstruktur sehingga diperlukan pemahaman yang sama antara pelaksana program dengan para Ketua Program Studi, Dekan, Badan Kemahasiswaan dalam mencapai kemandirian mahasiswa dan alumni dalam mengembangkan usaha.

- Perlu kerjasama antar perguruan tinggi yang mempunyai program IbK sehingga dapat dilakukan kerjasama dalam bentuk kegiatan bersama, misalnya: pameran produk, konsultasi bisnis, kontak bisnis, dll.

- Perlu kerjasama yang lebih intensif dengan stakeholders bidang usaha, antara lain : Kamar Dagang dan Industri (KADIN) Kota Malang, Dewan Kerajinan Nasional Daerah (Dekranasda) Kota Malang, serta Dinas terkait yaitu: Dinas Perindustrian dan Perdagangan, Dinas Koperasi dan UKM Kota Malang.

\section{DAFTAR PUSTAKA}

Hackathorn, Jana. Et.al. 2011. "Learning by Doing: An Empirical Study of Active Teaching Techniques". The Journal of Effective Teaching, Vol. 11, No. 2, 2011, 40-54.

Kasali, Rheinald. 2010. "Myelin, Mobilisasi Intangibles Menjadi Kekuatan Perubahan". Jakarta: PT Gramedia Pustaka Utama.

Kienan, Brenda. 2001. "Small Business Solution ECommerce". Frans Kowa (Pent.). Jakarta: Elex Media Komputindo.

Pujantiyo, Bambang. 2006. "Kiat Sukses Pengusaha Inovatif' Jakarta: Timpani Publishing. 